\title{
Trocando de mãos: o mercado de imóveis rurais em Ribeirão Preto (1874-1930) *
}

\author{
Renato Leite Marcondes * \\ Jorge Henrique Caldeira de Oliveira ${ }^{* * *}$
}

Mas não se deve confiar demais nos algarismos. O que vale a terra é na realidade muito mais do que as avaliações traduzem (Machado, 1980, p. 45).

\section{Resumo}

As negociações de terras acompanharam, ao longo dos séculos XIX e XX, os movimentos cíclicos de expansão, estabilização e retração da cafeicultura em território paulista. Ao analisarmos as escrituras de compra e venda de imóveis rurais de Ribeirão Preto verificamos um palco desse processo. Mesmo antes dos grandes plantios, ocorreu uma movimentação expressiva no mercado de terras, elevando os números e valores negociados. Grandes levas de fazendeiros, lavradores, escravos, colonos e imigrantes buscaram a região como meio para aproveitar o boom do café. Os investimentos elevaram as transações e seus valores no último quartel do século XIX, assim como o preço das terras aptas para novas plantações. No auge da produção cafeeira, nas primeiras décadas do século XX, houve uma acomodação do mercado, retraindo o volume de negociações. Na década de 1920 , observamos uma retração da produção de café, dos negócios e dos preços das terras disponíveis para novos cafezais, aumentando relativamente as transações urbanas.

Palavras-chave: Mercado de terras; Café; Ribeirão Preto; Preço das terras.

\begin{abstract}
\section{Changing hands: rural real estate market in Ribeirão Preto}

During the 19th and 20th centuries the negotiations in land sales and development followed the movement of expansion, stabilization and reduction in the coffee growing industry of the state of São Paulo. Analyzing the sale deeds of rural real estate and properties in Ribeirão Preto we obtain an overview of this process. Even before the large plantations, the land market had expanded, increasing property and land values. Large groups of farmers, agricultural workers, slaves, colonists and migrants came to the region looking for the wealth of the coffee boom. The investments increased the number of transactions and their values, as well as the price of lands suitable for plantation.

We notice this process during the last quarter of the 19th century. In the peak of coffee production (in the first decades of the 20th century) there was a market settlement, retracting the number of negotiations. In the 1920 s, we observe a reduction in coffee production and negotiations, as well as in prices of land available for new crops.
\end{abstract}

Keywords: Land; Coffee; Ribeirão Preto; Price of lands.

JEL N560.

* Trabalho recebido em 8 de outubro de 2010 e aprovado em 12 de novembro de 2011

** Professor de História Econômica do Departamento de Economia da Faculdade de Economia, Administração e Contabilidade de Ribeirão Preto da Universidade de São Paulo (FEA-RP/USP), Ribeirão Preto, SP, Brasil. E-mail: rlmarcon@usp.br.

*** Professor de Economia de Empresas do Departamento de Administração da FEA-RP/USP, Ribeirão Preto, SP, Brasil. E-mail: jorgecaldeira@usp.br. 


\section{Introdução}

A apropriação de terras no Brasil ocorreu por meio de um processo complexo, envolvendo a cessão de domínio pelos governos, o apossamento pacífico ou não, a aquisição por compra ou herança ${ }^{1}$. A pressão de uma atividade econômica em expansão conduziu, à medida que avançava a colonização, a uma valorização do solo, seja com a cana-de-açúcar, a mineração, o algodão, o café ou até mesmo com a pecuária. A preciosa rubiácea marcou o processo de ocupação em São Paulo durante o século XIX e início do XX. Aos poucos, a terra tornou-se uma mercadoria transacionada na sociedade rural $^{2}$. Nesse conjunto, pretendemos estudar uma das formas de apropriação, que foi a compra e venda de imóveis por meio das escrituras dos cartórios de notas.

Ribeirão Preto destacou-se na produção de café no final do século XIX e início do século XX, assumindo a liderança entre os municípios paulistas. Este artigo analisa o mercado imobiliário de Ribeirão Preto logo após a emancipação do município até o final da Primeira República, especialmente o de imóveis rurais. Objetivamos verificar a dinâmica desse mercado mediante alguns indicadores imobiliários, como, por exemplo, número de transações, valores dos bens comercializados e preço das áreas negociadas.

A fonte das informações é um conjunto de pouco mais de sete mil escrituras de compra e venda de imóveis depositadas no primeiro cartório de notas da cidade $^{3}$. Essa documentação informa a data da transação, o nome do comprador e devedor, o valor da transação e, de forma mais irregular, algumas características mais sumárias do imóvel (dimensões, benfeitorias, plantações mais perenes, etc.). A partir principalmente das informações mais regulares, podemos avaliar a dinâmica do fluxo dos negócios ao longo do período em estudo. Esse corpo documental foi pouco trabalhado pelos historiadores, sobretudo de forma mais seriada e quantitativa.

Na primeira seção, discutimos, com base na literatura disponível, o crescimento do mercado de terras em São Paulo, particularmente durante a marcha para oeste do café. Num segundo momento, apresentamos uma visão do conjunto das escrituras e o relacionamos com a dinâmica econômica e demográfica do

(1) Há uma vasta literatura acerca da questão. Entre os diversos estudos, destacamos os de Guimarães (1977), Lima (1988), Martins (1986), Silva (1996), Motta (1996) e Nozoe (2008).

(2) Os inventários post-mortem apontam para a importância relativa dos diferentes ativos ao longo do tempo. De início, os escravos da terra ou da África e as manufaturas importadas representavam os bens mais valiosos; posteriormente as terras ganharam maior importância (ver, por exemplo, Machado, 1980).

(3) As escrituras compulsadas estão depositadas no $1^{\circ}$ Cartório de Ofício de Ribeirão Preto. A separação dos municípios de Sertãozinho e Cravinhos deve ter restringido o espaço de abrangência territorial desse cartório. O primeiro foi criado em 1896 e instalado em 1897, o segundo, em 1897 e 1898, respectivamente. Utilizamos, adicionalmente, de forma pontual, alguns documentos depositados no Arquivo do Estado de São Paulo (AESP). 
município. Nas considerações finais, discutimos a valorização das terras em Ribeirão Preto com seus cafezais e benfeitorias.

\section{Mercado de terras em São Paulo}

A concentração fundiária atual não decorreu apenas do sistema legal de sesmarias em vigor durante o período colonial com a doação de largas extensões de terras aos mais afortunados, que as ocupavam muito parcialmente ${ }^{4}$. Naquela época, houve também a prática do apossamento de forma bastante disseminada, mesmo não reconhecida ou contestada. A propriedade fundiária colonial baseada no ordenamento das sesmarias era bastante precária:

O acompanhamento da legislação fundiária vigente durante o período em que o Brasil esteve sob domínio de Portugal deixa à mostra a precariedade da situação jurídica da propriedade fundiária, mesmo daquelas legalmente recebidas por mercê da Coroa. A quantidade e o tipo de exigências decorrentes do recebimento de tratos de terras em doação, ao lado das dificuldades ou o desinteresse dos beneficiários em cumpri-las, acabavam por colocar a maior parte delas em comisso, sujeitas portanto - da mesma forma como as posses -, à denúncia por terceiros (Nozoe, 2006, p. 589).

A partir da abolição do sistema, em 1822, a posse passou a ser a única forma de apropriação das terras, mais adaptada à agricultura móvel, rudimentar e predatória (cf. Silva, 1996). A lei de terras de 1850 procurou regular o acesso às terras devolutas, restringindo a compra (ver Martins, 1986). Para efetivar tal intento, era necessária a legitimação das posses e sesmarias com a sua demarcação, um cadastro de terras e a proibição de novas posses ${ }^{5}$. Entretanto, nenhuma dessas práticas foi aplicada após a regulamentação da lei. De acordo com Lígia Osório Silva, o processo de privatização das terras devolutas permaneceu:

A passagem das terras devolutas para o domínio privado, por meio da posse, continuou a ser praticada e contou para isso com uma legislação de apoio que alterava, em alguns aspectos, a lei de 1850. As modificações mais importantes diziam respeito: 1) à data de validade das posses que foi prorrogada até pelo menos o início do século XX e, em alguns casos, até bem depois; 2) à alteração dos prazos para as reavaliações de sesmarias e legitimação das posses (Silva, 1996, p. 335-336).

(4) A lei de sesmarias foi estabelecida em Portugal no final da Idade Média (1375). No caso colonial, houve uma adaptação, dado que toda a terra era de domínio público. Nelson Nozoe explica melhor o seu uso e limites no âmbito colonial: "Tendo sido concebida para solucionar questões peculiares ao reino português de fins do século XIV, a aplicação da lei das sesmarias no extenso e inexplorado território da colônia brasileira, não obstante as reiteradas tentativas de adaptação às condições aqui vigentes, resultou no uso mais ou menos generalizado da posse como recurso de acesso a terra, que culminou, por sua vez, com a suspensão das concessões de terras em sesmaria, em 1822.” (2006, p. 589).

(5) Ver lei 601 de 18 de setembro de 1850. 
A constituição republicana transferiu aos estados legislar sobre as terras devolutas. Em São Paulo, a legislação do final do século XIX legitimou as posses anteriores a 1878 e não a 1854, quando da regulamentação da lei de terras e da primeira ocupação até $1895^{6}$. Ainda no século XX, a grilagem de terras devolutas ocorria no estado, muitas vezes legalizadas posteriormente, como pela lei de $1921^{7}$. Num território vasto e desocupado, o apossamento continuou em vigor durante todo o século XIX e mesmo no século XX.

Apesar da fragilidade institucional apontada, existiam negócios com terras rurais muito antes da legislação de terras de 1850. Já no período colonial, as escrituras de compra e venda de imóveis foram utilizadas para registrar a troca de propriedade de bens rurais e urbanos ${ }^{8}$. Não obstante as precárias demarcações, atribuía-se valores às terras, embora relativamente pouco expressivos naquela época ${ }^{9}$. A partir principalmente da mineração do século XVIII, houve um aumento das transações e dos seus valores ${ }^{10}$. Ângelo Alves Carrara ressaltou a menor importância das sesmarias em comparação com a posse, para o caso de Minas Gerais, nas transações rurais:

É necessário ter sempre em mente que, desde o primeiro momento, constituiu-se em Minas um extenso mercado de terras, dadas as condições peculiares da circulação monetária realizada pela mineração, e o mercado de imóveis rurais foi outra forma de acesso à propriedade. As concessões sesmariais efetuadas entre 1710 e 1711 tão-somente flagraram parte da estrutura fundiária da capitania nesses anos. A rapidez como a propriedade

(6) Ver lei estadual 323 de 22/6/1895.

(7) A lei estadual 1844 de 27/12/1921 permitiu aos posseiros estabelecidos a pelo menos um ano obter títulos de terras. Desse modo, legalizou todas as posses efetuadas entre 1895 e1921, concedendo gratuitamente terras devolutas (cf. SILVA, 1996, p. 284-89).

(8) Antonio Carlos Jucá de Sampaio compulsou pouco mais de mil escrituras do Rio de Janeiro entre 1650 e 1750 (2000, p. 101 e 220). Desse total, verificou que pouco mais da metade referiam-se a bens rurais: partidos, engenhos, fazendas, sítios, benfeitorias e terras. Por outro lado, ao longo do período em análise, o autor verificou uma mudança relativa da importância dos valores da propriedade rural e urbana (casas, terrenos, sobrados, lojas, etc.) mediante a ascensão de uma elite mercantil integrada aos fluxos de comércio com o interior da colônia e fora dela.

(9) Alcântara Machado afirmou, para o período colonial paulista, que: "O quinhão maior não é representado pela propriedade imobiliária." (1980, p. 42). Nos séculos XVI e XVII, a terra nua detinha pouco valor, "em regra só as benfeitorias são avaliadas." (1980, p. 38). Um tecido fino importado custava mais do que uma légua de campo, e um lanço de casas no centro da cidade de São Paulo, não mais que três colchões, "Mas, em rigor, não há motivo para espanto. Que vale a terra sem gente que a povoe e aproveite? O que falta aos paulistas não é o chão, que aí está, baldio e imenso, à espera de quem o fecunde. Faltam-lhe, sim, a ferramenta, o vestuário, tudo quanto a colônia não produz ainda e tem de vir, através de obstáculos sem conta, da metrópole distante." (1980, p. 44). Segundo o autor, na realidade colonial, a terra valia muito mais do que as avaliações traduzem, determinando as relações sociais e econômicas.

(10) Antonio Sampaio notou um incremento do número de escrituras de bens rurais de 277 na segunda metade do século XVII para 377 na primeira metade do século XVIII (2000, p. 101). O valor médio desses bens cresceu comparativamente entre os dois períodos (2001, p. 101). Nas escrituras que apresentavam informações sobre a aquisição das propriedades rurais vendidas, a arrematação/compra e a herança foram as principais fomas de obtenção dos bens, representando mais de quatro quintos do total com informações (2000, p. 290). 
trocou de mãos, que as próprias concessões informam, tornaram as sesmarias instrumentos menores de acesso à terra (Carrara, 2001, p. 85).

Ao longo do século XIX, esse processo de valorização das terras ganhou impulso nas áreas mais dinâmicas, como as cafeeiras, mesmo antes da lei de terras de 1850. Ilustrativamente, podemos utilizar os dados apresentados por Carrara (2001, p. 94), segundo os quais ocorreu uma elevação dos preços da terra nas duas últimas décadas anteriores à regulamentação da lei na região da Zona da Mata Central, em Minas Gerais. Já para São Paulo, o engenheiro José Antonio Teixeira Cabral anotou o valor das terras e seus vários condicionantes em sua estatística da província de 1827:

O valor ou preço das terras varia muito segundo sua extensão, qualidade e distância da paróquia. Ele é sempre relativo à bondade do terreno, quero dizer, se é de massapé, se tem lugares elevados que, por sua posição topográfica, sejam isentos do flagelo das geadas e também acomodados ao fabrico do açúcar, onde este se faz; se tem matas virgens, boas aguadas e, finalmente, cercos naturais. Contudo, pode-se dizer geralmente que os terrenos próprios para a cultura da cana-de-açúcar e do café oferecem algumas vezes um preço máximo, cujo meio pode avaliar-se em 1:200\$000 réis por légua quadrada (Cabral, 2009, p. 48).

Cerca de dez anos mais tarde, Daniel Pedro Müller atualizou o valor da légua quadrada de terras de cultura da cana-de-açúcar e café sem benfeitorias para aproximadamente 1:400\$000 réis ${ }^{11}$. Se aceitarmos que uma légua quadrada tenha 9 milhões de braças quadradas e o alqueire paulista apenas 5 mil, chegamos ao preço por alqueire de terras nessas condições a somente 778 réis. Já no meado da década de 1870, Joaquim Floriano de Godoy informava a elevação do preço das terras apropriadas às culturas em São Paulo, inclusive mais caras que as do Rio de Janeiro, que, naquela época, era grande centro cafeeiro:

Ao passo que na província do Rio, comparativamente mais povoada, o alqueire de terra (de 10.000 braças quadradas) se vende geralmente na razão de $200 \$ 000$, nesta província, mesmo em lugares longínquos, alcançam de $200 \$ 000$ a $300 \$ 000$ por alqueire de terra contendo apenas 5.000 braças. (1978, p. 126)

Apesar da precariedade da comparação, o crescimento do valor das terras foi extraordinário por cerca de quatro décadas. A dinâmica crescente do valor das terras pôde ser observada em outras áreas cafeeiras e continuou após 1854, como no Oeste de São Paulo (Brioschi, 1991, p. 236). A terra transformava-se cada vez mais numa mercadoria transacionada entre particulares, em maiores volumes e valores.

(11) O texto é muito semelhante ao anterior: "O valor das terras de cultura varia segundo sua qualidade, extensão e distância à vila ou paróquia e porto do mar; entra em conta se tem matas virgens, boas aguadas, cercos naturais e posições elevadas livres das geadas." (Müller, 1978, p. 27). 
O roteiro do café incorporava constantemente novas terras para a sua produção; em contrapartida, as mais antigas e desgastadas eram paulatinamente abandonadas. Nessa dinâmica de apropriação, a busca de novas áreas de produção ganhou maiores proporções mediante o avanço do transporte ferroviário, viabilizado pelo café, possibilitando o seu cultivo em regiões mais distantes do litoral. O Oeste de São Paulo foi palco desse ato desde o meado do século XIX, gerando pressões para o desmantamento de novas áreas e, consequentemente, valorizando suas terras, muitas vezes antes da própria chegada do café ou da ferrovia $^{12}$. Particularmente, o período de 1880 a 1910 foi de rápida conquista do solo por uma massa de pioneiros em marcha para o oeste, formada por grandes fazendeiros, sitiantes, coronéis, grileiros, vendedores de terras e trabalhadores livres, composta, em sua maioria, por imigrantes nacionais e estrangeiros. Como afirmou Pierre Monbeig:

Só por comodidade de exposição distinguimos os fazendeiros dos vendedores de terras, e os imigrantes 'colonos' dos que compravam uma pequena propriedade, um sítio. Seria errôneo considerar que, no mundo pioneiro, a estratificação social comportasse separações rígidas e sobretudo intransponíveis, entre os grupos. Não é raro encontrar um fazendeiro que, alguns anos atrás, ainda era um simples colono. (...) São instáveis as fortunas, pois que as terras perdem rápido o seu valor e também porque, mais que a terra, o que traz a riqueza é o seu produto, café ou algodão, sujeitos às oscilações dos mercados mundiais. A sociedade pioneira é antes de tudo dinâmica (1984, p. 163).

A expansão cafeeira para o oeste e o norte de São Paulo produziu a incorporação de largas glebas de terras para a faina agrícola e de uma grande massa de imigrantes nacionais e principalmente estrangeiros (ver Holloway, 1984). A consolidação dessa produção conduziu a uma tendência geral de fragmentação das propriedades maiores por meio da partilha das terras. De acordo com Caio Prado Júnior, em São Paulo, bem como no restante do Brasil: "A pequena propriedade, pelo contrário, tem uma história mais recente. Constituiu-se depois da grande, e em regra às suas expensas. Primeiro vem a grande propriedade; depois, retalhando-se esta, surge a média e a pequena." (1945, p. 696). Para o autor, a formação dessas posses menores pode estar condicionada a quatro grupos de fatores: necessidade de braços para as fazendas, decomposição da fazenda, influência dos centros urbanos e as colonizações oficial e particular.

(12) Pierre Monbeig chega a falar numa certa "psicologia bandeirante" dos pioneiros paulistas: "Há nos brasileiros, mais frequentemente nos de Minas Gerais e de São Paulo, uma espécie de instinto que os impele sempre para diante, além da civilização. (...) Uma espécie de fascínio exerce sobre os espiritos a presença de terras desocupadas. (...) A sede de ganho rápido mantém-se continuamente desperta, por causa da facilidade de encontrar um solo virgem e altamente produtivo. Seria, de resto, inexato levar exclusivamente à conta do gosto do lucro a facilidade do paulista em deixar seu estabelecimento para fundar outro, não menos efêmero que o precedente. No fundo, a principal responsabilidade por esse nomadismo pioneiro recai sobre a estrutura econômica." (1984, p. 122-123). 
A expansão cafeeira na região das afamadas terras de Ribeirão Preto iniciou-se na década de 1870, mas o plantio avançou de forma mais expressiva nas duas décadas seguintes ${ }^{13}$. Os maiores volumes produzidos ocorreram nas primeiras décadas do século XX, anteriores à geada de 1918. Posteriormente, houve renovação das plantações e recuperação das colheitas, mas, em geral, inferiores ao patamar antes atingido, não ocorrendo, portanto, uma expansão dos cafeeiros (cf. Marcondes, 2007) ${ }^{14}$. O município apresentou um ritmo expressivo de crescimento econômico e demográfico nessa época. Essa grande mudança alterou a paisagem formada por pequenas roças de milho, arroz, cana e pecuária para uma "onda verde" de cafezais distribuídos por diversas fazendas, como no mapa abaixo ${ }^{15}$.

Ernesta Zamboni analisou, baseada em escrituras de compra e venda, a rede fundiária de Ribeirão Preto entre 1874 e 1900, mostrando uma dinâmica crescente dos negócios rurais, especialmente na última década do século XIX. Houve um processo de retalhamento e aglutinação de terras para a formação das grandes propriedades:

Como mostram os dados de registros de compra e venda (...) no período de 1874 a 1899, verificou-se que a maior parte das áreas vendidas não ultrapassa 100 ha. Ao analisarmos esta afirmação destacamos dois aspectos: $1^{\circ}$ ) os

(13) Renato Leite Marcondes observou, referente ao estoque de cafeeiros existentes no município, que: "Neste período, dos quase trinta milhões de pés existentes em Ribeirão mais de quatro quintos tinham seis anos ou mais de idade. Destarte, podemos observar que a grande maioria dos cafezais de Ribeirão Preto em 1901-02 foram plantados entre o segundo lustro da década de 1880 e o primeiro da seguinte. Esse grande plantio beneficiou-se de preços favoráveis daquela época, principalmente ao final da década de 1880. Posteriormente, não ocorreu mais a expansão significativa do número de cafeeiros, tão-somente a renovação dos pés mais velhos, deteriorados ou danificados." (2007, p. 177).

(14) Rogério Faleiros analisou os contratos de plantio de café da região mogiana. O autor verificou um volume expressivo de novos contratos logo após a geada, porém, posteriormente, o número revelou-se reduzido, muito inferior ao de Franca (2007, p. 133).

(15) Existem várias evidências referentes a Ribeirão Preto, no início do século XX, de uma ocupação expressiva do seu território. O relatório do $3^{\circ}$ Distrito Agrícola de 1900 menciona a escassez de gêneros alimentícios e matas: "em primeiro lugar a magna questão dos cereais e grãos alimentícios; tornando cada dia mais extensiva a lavoura cafeeira, derrubando e queimando as poucas matas que restam para que possa ai centuplicar o número de pés de café..." (AESP, Ordem 5573, p. 17). Nesse momento, dos quase 43 mil alqueires de área total, cerca de um terço era plantado com café. De modo semelhante, a estatística agrícola de Ribeirão Preto em 1904-05 informava que "Ribeirão já não tem matas, e na pouca existente ainda se encontram: óleos, perobas. [...] Ribeirão Preto importa madeira de toda a parte" (Secretaria da Agricultura, Comércio e Obras Públicas, 1907). Nesse documento, verificamos a existência de 261 estabelecimentos agrícolas. O valor do solo por alqueire dessas propriedades oscilava entre $20 \$ 000$ e $400 \$ 000$ réis, mas, em geral, o valor mais frequente era de $100 \$ 000$ e, principalmente, de 200\$000. Constatou-se apenas quatro situações em que os valores eram inferiores a setenta mil-réis, dos quais três se referiam a terras não roxas, denominadas "brancas". Apesar de constar como minoria no município (18 casos), algumas terras "brancas" detinham valores superiores a cem mil réis, incluindo um caso de duzentos mil réis e cinco de 150\$000. O serviço de inspeção agrícola de 1910 a 1912 , por sua vez, apontou que um hectare de terra de boa qualidade, em Ribeirão Preto, custava $600 \$ 000$ réis. Ademais, o documento também informava a inexistência de matas (Ministério da Agricultura, Indústria e Comércio, 1912, p. 360). 
pequenos proprietários venderam suas terras ou parte delas diante das dificuldades econômicas de organizarem fazendas produtoras de café $2^{\circ}$ ) os grandes proprietários territoriais, como por exemplo os Junqueiras, parecem ter vendido parte de suas propriedades movidos pela especulação fundiária ocorrida por ocasião da penetração dos cafezais e pela valorização do café no mercado internacional (Zamboni, 2001, p. 206).

A aquisição de pequenas áreas de terra por compra possibilitou o ressurgimento das grandes propriedades, especialmente por parte daqueles que detinham capitais próprios ou acesso aos de terceiros. Não raro, os recursos para a compra originaram-se de capital estrangeiro, como no caso de Francisco Schmidt, financiada pela casa importadora alemã Theodor Wille ${ }^{16}$. O capital estrangeiro também adquiriu propriedades em Ribeirão Preto e região, a exemplo da Companhia Agrícola Fazenda Dumont e a São Paulo Coffee States pelos ingleses ${ }^{17}$. Observamos, portanto, a importância de tais documentos para o entendimento da conformação da estrutura fundiária da região. Em nosso caso, procuramos expandir a análise das escrituras de Ribeirão Preto.

Mapa das fazendas do município de Ribeirão Preto

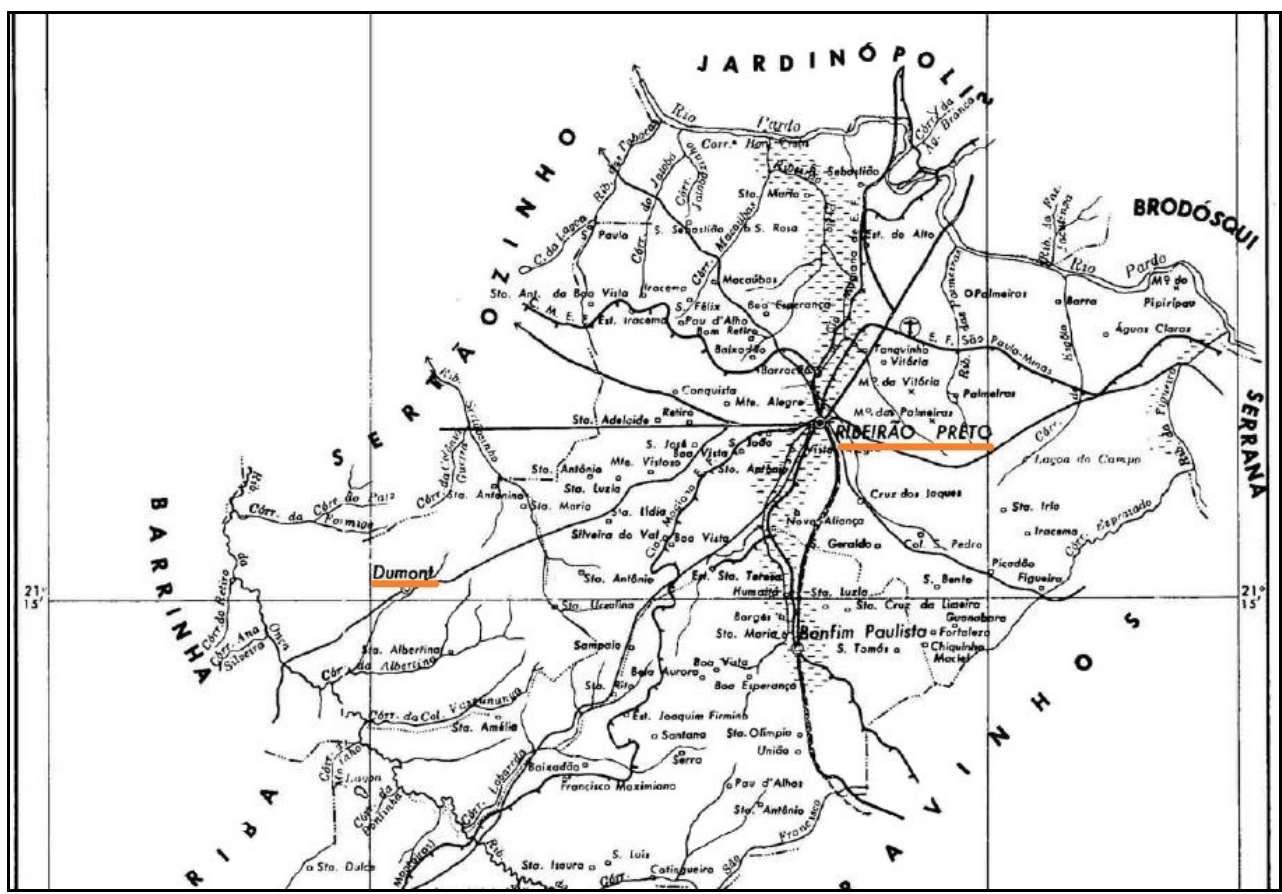

Fonte: IBGE. Enciclopédia dos Municípios Brasileiros. Rio de Janeiro: IBGE, 1960, v. 11, p. 325.

(16) Ver, para maiores informações, a dissertação e a tese de Maria Luiza de Paiva Mello Moraes (1980 e 1988). Entre as fazendas adquiridas por Schmidt estava a Monte Alegre.

(17) Ver a dissertação de Silvio Zamboni (1979). 


\section{Escrituras de Ribeirão Preto}

No último quarto do século XIX, predominaram as transações no âmbito rural em Ribeirão Preto decorrentes da expansão cafeeira numa área de escasso povoamento urbano. A influência da preciosa rubiácea mostrou-se marcante nas escrituras à medida em que se intesificou a busca pela aquisição de terras para o seu cultivo, especialmente por imigrantes nacionais e posteriormente estrangeiros. Os negócios que marcaram a mudança da paisagem rural da região foram as duas primeiras compras efetuadas por Luís Pereira Barreto em junho de 1876. A soma das duas aquisições totalizou 32,5 contos de réis, superando em larga monta o padrão de negociação do início de nosso período de estudo ${ }^{18}$. No conjunto de transações até então (1874-76), o valor médio das negociações chegou somente a 1,6 contos de réis.

A primeira propriedade adquirida por Luís Pereira Barreto detinha 80 alqueires de terras de cultura, a segunda, uma fazenda sem especificação de tamanho. Contudo, já existia, nesta última, uma pequena plantação de café com as seguintes benfeitorias: duas moradas de casas assobradadas, paióis, engenho de moer cana, cercas, currais, seis alqueires de roças de milho e 50 porcos ${ }^{19}$. Essa compra de Pereira Barreto sinalizou a realização de investimentos - de acordo com o entusiasmo mostrado em seus artigos nos jornais paulistas e cariocas -, inaugurando uma fase de mudanças em Ribeirão Preto, muitas vezes chamada de "rush" à região, com a chegada de entrantes de outras regiões, inclusive de áreas cafeeiras estagnadas ou já decadentes ${ }^{20}$.

Ainda nesse ano, apenas seis meses após essa compra, outro membro da família também adquiriu terras em Ribeirão Preto. Em 28 de dezembro de 1876, Augusto César Pereira Barreto (irmão de Luís) comprou terras de Antonio Baptista dos Santos e de outros vendedores por 14,4 contos de réis, tornando-se a segunda maior negociação nesse período inicial. Essa propriedade compreendia 180 alqueires, sendo uma negociação simultânea com diversos vendedores locais. Entre as benfeitorias da fazenda, destacavam-se roças, porcos, duas casas cobertas de telhas, dois monjolos, pastos e plantação de milho, ou seja, atividades típicas de

(18) Cartório do $1^{\circ}$ Ofício de Ribeirão Preto, Livro n. 5, p. 107 e Livro n. 4, p. 88.

(19) Cartório do $1^{\circ}$ Ofício de Ribeirão Preto, Livro n. 4, p. 88.

(20) Vários artigos no Estado de São Paulo apontavam para a qualidades das terras roxas da região de Ribeirão Preto. Ilustrativamente, em 30 de julho de 1876, o engenheiro da Companhia Paulista Castro Barbosa já indicava a valorização dessas terras. O próprio Luís Pereira Barreto escreveu no "A Província de São Paulo" em 10 de dezembro de 1876: "Ribeirão Preto é o vasto repositório em que a 'Flora Brasileira' se ostenta em sua mais enérgica e deslumbrante expressão. É a esse município que eu aconselharia uma visita a todos aqueles que duvidam do testemunho paulista, e a todos aqueles que aprenderam a achar um supremo gozo nos grandes contatos com o mundo criador, no grandioso espetáculo da natureza viva. Graças às suas terras excepcionais, a província de São Paulo é a única que escapará ao naufrágio geral da nossa lavoura." (p. 2).O irmão de Luís Pereira, José Pereira Barreto, organizou uma caravana de pessoas livres e escravos para a região em 1876. Posteriormente, adquiriu uma propriedade, em 1878, no valor de 3:400\$000, perfazendo 82 alqueires. 
subsistência $^{21}$. Outro conhecido fazendeiro, que também fez propaganda das qualidades das terras, clima e altitude para o cultivo do café, foi Martinho Prado Júnior $^{22}$. Ele comprou suas seis primeiras propriedades em 1879 e 1880, infelizmente muitas delas sem informação de área.

A partir desse momento, as transações cresceram expressivamente, acompanhando o plantio dos cafezais $^{23}$. Como veremos adiante, aos poucos, o núcleo urbano também iniciou uma dinâmica expressiva, apoiando, num primeiro momento, o desenvolvimento cafeeiro e, posteriormente, superando as negociações em termos do número de transações. Na Tabela 1, fornecemos uma visão de conjunto das pouco mais de sete mil escrituras de compra e venda de imóveis, analisadas nesta pesquisa, entre 1874 e 1930. Desse total, pouco menos de um terço transacionou bens rurais, principalmente terras, sítios e fazendas, e, em consequência, as demais foram negociações de bens urbanos ${ }^{24}$.

Tabela 1

Número e valor real total das escrituras urbanas e rurais

(1874-1930)

\begin{tabular}{l|c|c|c}
\hline & Bens urbanos & Bens Rurais & Total \\
\hline Número de escrituras & 4.918 & 2.192 & 7.110 \\
\% de escrituras & $69,2 \%$ & $30,8 \%$ & $100,0 \%$ \\
Valor total (em contos & 11.401 & 32.140 & 43.541 \\
de réis) & $26,2 \%$ & $73,8 \%$ & $100,0 \%$ \\
\% Valor total & 2,318 & 14,663 & 6,124 \\
Valor Médio &
\end{tabular}

Obs.: Em muitos casos, houve dificuldade para definir a propriedade como urbana ou rural, especialmente as localizadas em áreas suburbanas. Utilizamos informações sobre localização, tamanho e ocupação para caracterizar um imóvel como urbano ou rural.

(21) Cartório do $1^{\circ}$ Ofício de Ribeirão Preto, Livro n. 7, p. 125. A família Pereira Barreto comprou diversas propriedades nos anos seguintes, sendo que o próprio Luís Pereira Barreto adquiriu mais quatro. Em conjunto, essa família comprou dezoito propriedades entre 1876 e 1885, das quais o irmão de Luís Pereira, Rodrigo, adquiriu quatro, Augusto, três, José, duas, Francisco, uma e Candido outra.

(22) Estado de São Paulo, 14,16, 18 de outubro de 1877

(23) Em 1880, Henrique Dumont comprou, de José Bento Diniz Junqueira, um sítio com terras de cultura de primeira sorte e casa de morada por 120 contos. Essa foi a primeira aquisição de outras dez que ocorreram posteriormente entre 1884 e 1890; algumas já detinham cafezais. Ainda em 1890, a então Companhia Agrícola Fazenda Dumont contraiu um empréstimo, por meio de hipoteca, junto ao Banco União de São Paulo, totalizando 500 contos. As características do conjunto das propriedades foram registradas do seguinte modo: "Uma grande propriedade rural que se compõem de todas as terras, cafezais e benfeitorias, com cerca de 7 mil alqueires de terras ou 17 mil hectares e 940 ares de terras, 2 milhões de pés de café, casas de máquinas, terrenos pastos e todos os acessórios da mesma propriedade.” (Cartório de Imóveis de Ribeirão Preto, Livro 2). Essa companhia era a principal unidade produtora de café do município e, com certeza, uma das maiores do estado, contrastando fortemente com a realidade das fazendas descritas nas escrituras da década de 1870 .

(24) Não incluímos pouco mais de uma centena de escrituras que tratavam tão somente de bens móveis, como camas, mercadorias, carros, produtos agrícolas, etc. Estes últimos foram adquiridos principalmente pela comercialização da produção de café e de outros produtos, como o algodão e o açúcar. 
Ao contrário do número de transações, os negócios rurais representaram, em termos de valor real, para todo o período estudado, cerca de três quartos das negociações ${ }^{25}$. O valor médio dessas escrituras atingiu quase quinze contos contra um valor médio de pouco mais de dois contos de réis para as escrituras urbanas, reforçando o caráter rural da sociedade daquela época. Essas diferenças de médias mostraram-se compreensíveis, dado que, no meio urbano, as negociações restringiam-se a casas e terrenos e, no meio rural, os negócios envolviam muitas vezes terras com mais de 100 alqueires e culturas valorizadas, como a do café. Desse modo, podemos afirmar a maior importância dos negócios imobiliários no ambiente rural em relação ao urbano no conjunto das escrituras analisadas entre 1874 e 1930.

Ao longo do período em questão, podemos notar a dinâmica dos negócios imobiliários, especialmente em termos do número de transações, no Gráfico 1. As negociações rurais foram preponderantes numericamente no último quartel do século XIX. No início, houve um crescimento expressivo de 16 escrituras, em 1874, para 81, em 1878, num primeiro boom de negócios, acompanhando a propaganda, nos jornais, de Pereira Barreto e Martinho Prado. Contudo, o maior volume de negociações do período ocorreu a partir de 1885, provavelmente resultante da expansão agrícola com a chegada dos trilhos da Companhia Mogiana de Estradas de Ferro ${ }^{26}$. A Mogiana propiciou uma nova dinâmica para os negócios em Ribeirão Preto, facilitando o transporte do café e o deslocamento de pessoas. Esse patamar ao redor de uma centena de transações por ano manteve-se até o início da década de 1890, alcançando um pico de 126 escrituras em 1890, favorecido também pela conjuntura nacional de expansão do Encilhamento ${ }^{27}$. Após

(25) Utilizamos, entre 1873 e 1913, o índice de preços construído por Catão (1992) e, para o período restante, o índice de custo de vida da cidade do Rio de Janeiro, disponibilizado no site do IBGE. Os valores reais estão em moeda de 1913.

(26) Pierre Denis salientou, no início do século XX, um movimento mais amplo em São Paulo nessa época: "O ano de 1885 marca o início da grande febre das plantações de café. Havia trinta anos já que a cultura do café fazia em São Paulo regulares progressos; mas nada deixava prever o extraordinário desenvolvimento das plantações, que se manteve desde 1885 até 1900 aproximadamente. Durante estes 15 anos, a plantação do café preocupou exclusivamente todos os espíritos. Interessou a agricultura e a colonização, pobres e ricos, citadinos e camponeses. Como sempre sucede em tais circunstâncias, um movimento universal de especulação sobre as terras ativou o movimento colonizador. (...) a colonização concentrada, metódica, deu-se a descobrir terras convenientes ao cafezeiro. Sendo a terra violeta a melhor terra para o café, houve verdadeiramente uma caça aos filões de diábase. É o momento em que o estado de São Paulo se cobre de caminhos de ferro. Muitos agricultores abandonam nesse momento as antigas terras das velhas regiões agrícolas para irem se fixar-se mais longe. (...) O centro de gravidade do estado deslocou-se. A nova cidade de Ribeirão Preto tornou-se rival de Campinas" (s.d., p. 142-143). Ver, sobre a ferrovia, Gitel Vugman (1976).

(27) O boom econômico nacional perdurou por mais alguns anos, bem como os preços favoráveis externos e principalmente internos do café. Ainda assim, o número de transações rurais em Ribeirão Preto declinou nos primeiros anos da década de 1890. 
esse período, não houve uma recuperação do número de negócios imobiliários rurais, inclusive nas primeiras décadas do século XX quando da política de defesa do café. Mesmo os anos de crescentes negócios rurais anteriores à Primeira Grande Guerra não atingiram patamar semelhante ao da febre dos negócios dos anos 1880 e início da década de 1890, que revelou um boom dos negócios relacionados à expansão dos cultivos cafeeiros ${ }^{28}$.

Gráfico 1

Número de escrituras rurais e urbanas (1874-1930)

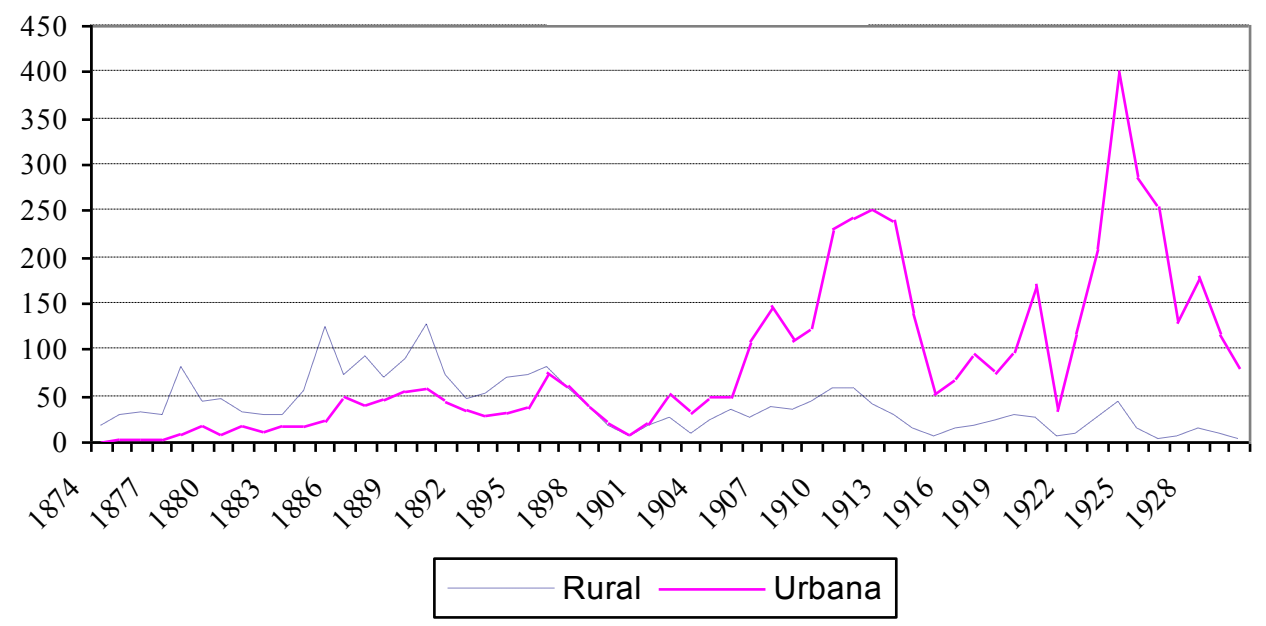

As negociações urbanas apresentaram, de forma mais expressiva que as rurais, uma tendência de crescimento do número de escrituras desde o final da década de 1870 até o final do século XIX quando a retração dos preços do café e a política restritiva efetuada por Joaquim Murtinho para a estabilização da economia produziram uma desaceleração do conjunto das transações ${ }^{29}$. Na passagem do século XIX para o século XX, as transações urbanas tornaram-se mais numerosas que as rurais, assumindo uma forte expansão nos anos anteriores à Primeira Grande Guerra. A guerra retraiu todos os tipos de negócios, até mesmo urbanos, e a recuperação, nos anos 1920, mostrou-se ainda mais instável. Ao final do período em estudo, a grande maioria das transações referiu-se a bens urbanos, sinalizando a mudança que ocorreria posteriormente na economia do município, menos atrelada à cultura do café. Desse modo, para esse importante município cafeicultor, verificamos movimentos distintos entre o número de escrituras rurais e urbanas

(28) De acordo com o relatório do prefeito referente ao ano comercial de 1901-02, mais de dois terços dos cafeeiros existentes no município, naquele momento, decorriam de plantios da segunda metade da década de 1880 e o primeiro lustro da década de 1890 (Prefeitura de Ribeirão Preto, 1903).

(29) Sobre esta última década do século XIX, consultar Gustavo Franco (1983). 
ainda antes de 1930, sendo as primeiras mais frequentes no início do período e as segundas, no final ${ }^{30}$.

Não obstante a existência de uma sociedade essencialmente rural, os imóveis urbanos também se apresentavam de forma marcante no mercado imobiliário. A urbanização das cidades do oeste de São Paulo decorreu principalmente das diversas necessidades comerciais, industriais e de serviços privados e públicos para o desenvolvimento da economia cafeeira, bem como da vida religiosa e da administração pública municipal ${ }^{31}$. Já nos primeiros anos em análise, verificamos transações desse meio que se ampliaram consideravelmente ao longo do tempo, assumindo, primeiro, maior importância numérica e, depois, de valor. Ademais, a população urbana mantinha relações econômicas com o meio rural como, por exemplo, no que se refere à reserva de mão de obra para as fazendas de café, especialmente, no caso de Ribeirão Preto, do Núcleo Colonial Antônio Prado ${ }^{32}$. Os fazendeiros enfrentavam o problema da sazonalidade relacionada à necessidade de mão de obra, que aumentava bastante durante a época de colheita e que poderia ser suprida pelos cidadãos da cidade. Destarte, a crescente urbanização propiciou uma participação cada vez maior no mercado imobiliário do município.

No Gráfico 2, verificamos, em valores reais, uma flutuação muito semelhante ao notado para o número de transações imobiliárias ${ }^{33}$. O volume expressivo das negociações de imóveis rurais entre 1885 e 1896, salienta o movimento de investimentos por meio da aquisição de propriedades e de plantio, bem como a participação de grande contingente de imigrantes ${ }^{34}$. Como ocorreu

(30) Não é significativa a correlação entre o número de escrituras rurais e urbanas $(-0,17)$, pois os movimentos se mostraram divergentes ao longo do período em questão. Assim, realizamos a análise em separado das escrituras rurais e urbanas.

(31) Para uma análise da relação café e urbanização no interior de São Paulo, ver o estudo de Maria Coleta de Oliveira (1988). Algumas atividades mostravam-se diretamente envolvidas no transporte, armazenagem e beneficiamento do café, porém, a grande maioria não revelava relação direta com a principal cultura do município no período. Os relatórios e impostos municipais de Ribeirão Preto demonstram a existência de um grande contingente de pessoas ocupadas em outras atividades, como operários, comerciantes, transportadores, etc. (cf. Lopes, 2004; Marcondes; Garavazo, 2004).

(32) Na maior parte das escrituras, consideramos os imóveis pertencentes ao Núcleo Colonial Antonio Prado como urbanos, embora, muitas vezes, produzissem café, compreendendo áreas consideráveis, semelhantes às de fazendas. Nestes últimos casos, optamos por considerá-los rurais. Desse modo, a fronteira entre o urbano e rural não pode ser estabelecida de forma rígida.

(33) Se considerarmos, em separado, as escrituras rurais, notamos uma elevada correlação entre o número e o valor real $(0,65)$. De igual modo, as escrituras urbanas revelam uma correlação muito elevada entre número e valor real $(0,89)$.

(34) Ao final da década de 1879 , as escrituras começaram a registrar a vocação das terras para o cultivo da preciosa rubiácea como uma característica que valorizava as propriedades. Um exemplo é esta a escritura de 1879: "50 alqueires de terras de cultura superior de $1^{a}$ sorte própria para plantação de café." Posteriormente, quando já havia o plantio recente de café indicavam, como nesta escritura de 1885: "pés de café plantados no ano passado" ou nesta outra de 1889: "plantados este ano". 
em relação ao número de escrituras, tais patamares também não foram alcançados novamente mesmo no período subsequente, inclusive nos anos de crescimento dos negócios anteriores à Primeira Grande Guerra.

O sucesso da produção de café em Ribeirão Preto transformou a propriedade da terra num atrativo para os fazendeiros locais e oriundos de outras regiões. Nessas primeiras décadas, os volumes de imóveis rurais negociados superaram em larga monta o total dos urbanos, porém, no início do século XX, uma maior aproximação dos valores, resultou, em 1906, pela primeira vez, em uma inversão dos mesmos, num ano emblemático da crise do café. A partir de 1913, verificamos certa equivalência entre os valores rurais e urbanos transacionados, alternando um e outro na liderança dos negócios. Apesar dos menores valores dos imóveis urbanos, o aumento do número de negócios desse tipo possibilitou o equilíbrio no valor total negociado. Como verificado para o número, os valores reais transacionados para os imóveis rurais e urbanos não se mostraram estatisticamente correlacionados $(0,15)$. As transações urbanas e rurais revelaram, no conjunto do período, comportamentos distintos, apontando uma trajetória mais própria das urbanas e outra mais independente das rurais. Desse modo, nas décadas de 1910 e 1920, esses valores foram semelhantes. Contudo, não houve superação, de forma significativa, do valor dos negócios urbanos em relação aos rurais, mas, sim, uma equivalência antes de 1930.

\section{Gráfico 2}

Valor real das escrituras rurais e urbanas (1874-1930)

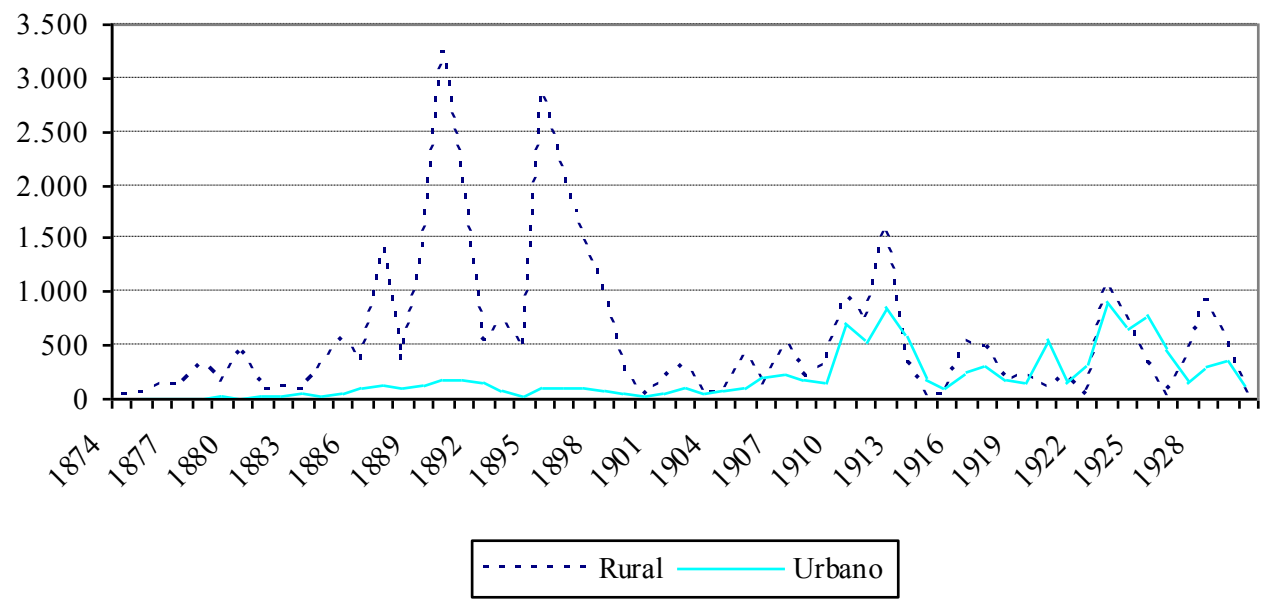

Não observamos modificações nas transações rurais em consequência das alterações da legislação referente às posses de terras no estado, como em $1895 \mathrm{e}$ 1921. A legalização de áreas poderia incentivar o aumento das negociações, seja em número ou valor, porém não verificamos tais modificações nas séries 
apresentadas nos dois gráficos. A ocupação dos terrenos na região desde o início do século XIX diminuiu a incidência de terras nessas condições, embora existissem conflitos pela posse ${ }^{35}$. Destarte, ao que tudo indica, o reconhecimento da legalidade das posses mais recentes não favoreceu a maior negociação de áreas no município de Ribeirão Preto. Provavelmente, as terras nessas condições já eram negociadas antes mesmo da própria legalização, como, com frequência, também as áreas pro indiviso (em condomínio) ou sem a dimensão ou divisas claramente determinadas.

Nos primeiros anos, os valores médios dos negócios rurais começaram ao redor de um conto de réis. Já no conjunto dos cinco anos iniciais, a média cresceu para pouco mais de quatro contos. A dinâmica desse mercado foi crescente, atingindo, no último lustro do século XIX, quase trinta contos de réis. Houve uma retração posteriormente, mas, ao final da década de 1920, os valores médios chegaram a quase cinquenta contos. Apesar da tendência crescente ao longo do tempo, os valores são marcados principalmente pelas diferenças de tamanho e das benfeitorias das propriedades ${ }^{36}$. Desse modo, podemos analisar em separado os fatores que condicionaram os montantes das transações.

Um dos elementos mais marcantes da valorização das propriedades foi a existência e a dimensão dos cafezais; não apenas a indicação das terras serem próprias para o café, mas, principalmente, a presença dos cafeeiros que requeriam investimentos e tempo para produzir. De início, a documentação retratou apenas a presença de cafezais e, aos poucos, quantificou a sua dimensão. Uma ilustração desses momentos iniciais da rubiácea pode ser observada nesta escritura de 1885: "cafés no quintal" numa propriedade de três alqueires ${ }^{37}$. No Gráfico 3, verificamos a evolução da informação sobre a presença de cafezais e seu tamanho. Os movimentos mais gerais observados foram semelhantes aos já comentados para o número e os valores reais das escrituras rurais, com um crescimento expressivo na década de 1880, revertido, de forma mais expressiva, no final do século XIX. Ao longo da primeira década do século XX, também ocorreu um boom de negócios até o momento anterior à Grande Guerra. Nos anos 1920, houve algumas transações expressivas, mas não nos montantes de cafezais e pés já atingidos anteriormente, refletindo uma menor dinâmica da economia cafeeira no município, especialmente após a Grande Guerra e a geada de 1918.

(35) Como faz referência Carlos de Almeida Prado Bacellar a um processo de Franca de 1827: “axando terras devolutas lançarão nellas posses, roçando, e derrubando Mattos em todas as barras, e levantando cruzes e desde logo denominarão todo o terreno assim possiado e adquirido (...)” (1999, p. 93).

(36) A regressão do valor em função do tamanho do cafezal e da propriedade demonstrou um poder explicativo bastante elevado, atingindo um R2 ajustado de 0,74. Como esperado, as duas variáveis explicativas foram significativas e apresentaram sinal positivo. A variável ano não foi significativa e, da mesma, forma a constante.

(37) Cartório do $1^{\circ}$ Ofício de Ribeirão Preto, Livro n. 18, p. 957. 


\section{Gráfico 3}

Cafezais e número de pés transacionados (1874-1930)

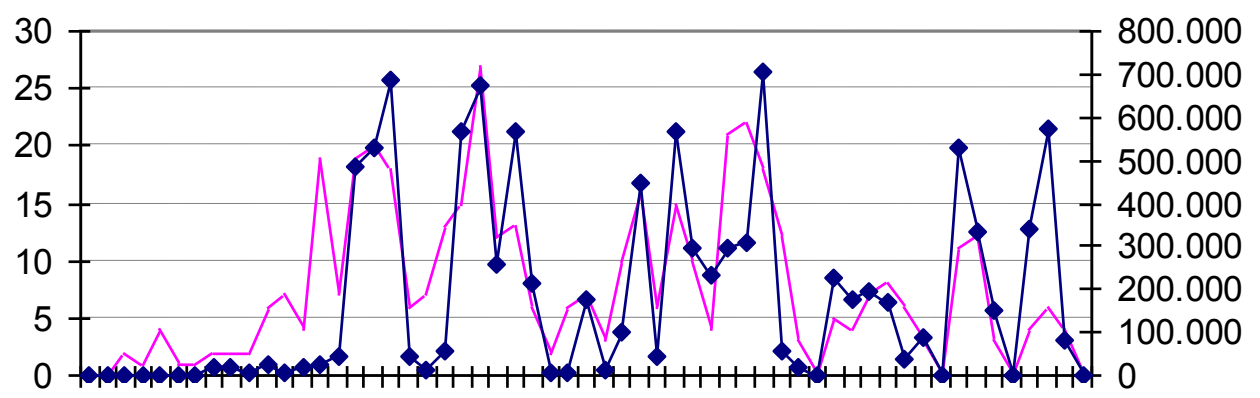

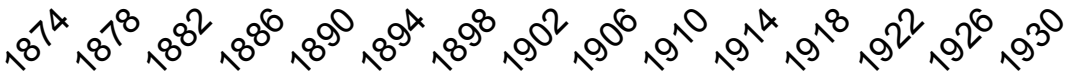

Cafezais $\multimap \longrightarrow$ Pés de café

A análise em separado da quantidade de pés de café por faixas de tamanho também nos auxiliou no entendimento do porte das propriedades transacionadas. De um total de 442 imóveis que continham cafezais, 318 detalhavam o número de pés de café existentes. Como podemos ver na Tabela 2, desse total de negócios, quase a metade possuía até 10 mil pés de café $(43,7 \%)$, o que podemos caracterizar como pequenos cafezais. Numa faixa intermediária, de 10 mil a 99 mil pés, verificamos a presença de quase a metade do total $(47,4 \%)$. Os poucos que detinham 100 mil ou mais pés de café representavam $8,8 \%$ dos possuidores de cafezais. Por outro lado, efetuando a soma das duas primeiras categorias, ou seja, fazendas com pequenos e médios cafezais - até 10 mil pés e de 10 a 50 mil pés de café -, temos um total de $77,0 \%$ dos negócios com descrição do tamanho dos cafezais. Isso significa que aproximadamente três quartos do total de fazendas negociadas detinham cafezais plantados e continham cafezais pequenos $(43,7 \%)$ ou médios $(33,3 \%)$.

Tabela 2

Tamanho dos cafezais segundo faixas

(1874-1930)

\begin{tabular}{l|c|c|c|c}
\hline Faixas de tamanho & Número & \% Número & Cafezais & $\%$ Cafezais \\
\hline Menor de 10 mil & 139 & $43,7 \%$ & 556.064 & $5,3 \%$ \\
10 a 49 mil & 106 & $33,3 \%$ & 2.387 .247 & $22,9 \%$ \\
50 a 99 mil & 45 & $14,2 \%$ & 3.090 .600 & $29,7 \%$ \\
100 mil ou mais & 28 & $8,8 \%$ & 4.391 .000 & $42,1 \%$ \\
Total & 318 & $100,0 \%$ & 10.424 .911 & $100,0 \%$ \\
\hline
\end{tabular}


Apesar da importância relativa dos pequenos e médios cafezais, isso não significa que a estrutura fundiária ou de posse de pés de café fosse desconcentrada em Ribeirão Preto. Para complementarmos os resultados alcançados, serão necessários estudos específicos a respeito da distribuição da produção de café e de terras. Ressaltamos, novamente, a necessidade dessa análise, visto que os estudos em escrituras apontam para a compra de pequenas fazendas contendo cafezais por grandes fazendeiros, agregando áreas, como relatado, para o período do século XIX, por Ernesta Zamboni (2001) e Oliveira e Marcondes (2003). Nesse sentido, também para o período mais amplo de 1874 a 1930, compreendido neste estudo, poucas grandes propriedades foram transacionadas. Entre as pequenas e médias, foram registrados negócios realizados por influentes cafeicultores ${ }^{38}$. Desse modo, a compra de pequenas sortes de terras e cafezais constituía-se numa estratégia para o crescimento das grandes propriedades.

\section{Preço da terra}

Antes de avaliarmos o comportamento dos preços das terras, é necessário separar os diversos fatores de valorização das propriedades negociadas. Podemos analisar, de forma mais geral, a ocupação das propriedades transacionadas na Tabela 3.

Tabela 3

Escrituras rurais segundo a ocupação do imóvel

(1874-1930)

\begin{tabular}{l|c|c|c|c}
\hline \multirow{2}{*}{ Ocupação } & \multicolumn{2}{|c|}{ Total } & \multicolumn{2}{c}{ Imóveis com área especificada } \\
\cline { 2 - 5 } & $\mathrm{N}^{\mathrm{o}}$ & $\%$ & $\mathrm{~N}^{\mathrm{o}}$ & $\%$ \\
\hline $\begin{array}{l}\text { Terras nuas } \\
\begin{array}{l}\text { Terras com } \\
\text { benfeitorias }\end{array}\end{array}$ & 948 & $46,0 \%$ & 415 & $39,3 \%$ \\
$\begin{array}{l}\text { Terras com } \\
\text { cafezais }\end{array}$ & 395 & $34,8 \%$ & 378 & $35,8 \%$ \\
Total & 2.060 & $19,2 \%$ & 263 & $24,9 \%$ \\
\hline
\end{tabular}

Obs.: Ainda restaram 132 escrituras em que não conseguimos classificar a ocupação do imóvel, entre as quais 70 apresentavam informações sobre a área.

Procuramos, portanto, separar os imóveis rurais transacionados pelas características de ocupação registradas nas escrituras. Dividimos as negociações em três grupos: terras nuas, terras com benfeitorias (mas sem pés de café) e terras com cafezais (com ou sem benfeitorias). A identificação de "terras nuas" refere-se àquelas que não continham qualquer tipo de benfeitoria - tais como casa de morada, monjolo,

(38) Embora se trate de uma informação de origem distinta, o recenseamento agrícola de 1904-05 apresenta 59 cafeicultores com 100 mil ou mais pés de café, salientando a importância das grandes propriedades, que, no entanto, foram pouco negociadas na sua integralidade. 
engenho, etc. - ou plantação, quer seja de café, quer seja de outro cultivo. Essas terras poderiam ser incorporadas à produção cafeeira por meio de novos investimentos $^{39}$. Do total de 2.060 negócios rurais com detalhamento de ocupação, pouco menos da metade era de terras nuas. As restantes dividiam-se entre terras com benfeitorias $(34,8 \%)$ e cafezais $(19,2 \%)$.

Pouco mais da metade das escrituras classificadas em termos de ocupação incluiam informações sobre a área negociada ${ }^{40}$. Os imóveis rurais com cafezais apresentavam, com mais frequência, a dimensão da propriedade em comparação ao total de escrituras. Desse modo, podemos calcular o preço do alqueire de terra de acordo com a ocupação. No Gráfico 4, fornecemos os preços médios das terras nuas, de 1875 a 1930, que apresentaram uma tendência de crescimento especialmente no século $\mathrm{XIX}^{41}$. Essa valorização das terras mostrou-se notória, pois o primeiro valor médio do alqueire para terras nuas alcançou apenas seis mil réis em 1875 e, em 1879, o preço atingiu quase 62 mil réis. Posteriormente, no final da década de 1880, os preços alcançaram um patamar superior a cem mil réis, mantendo propensão ascendente até meados de 1890. A partir desse momento, os preços apresentaram maior oscilação, sem tendência definida, até à Primeira Grande Guerra, o que conduziu a uma retração dos valores das terras. Ademais, os problemas relativos às safras, decorrentes, especialmente, da geada de 1918, deprimiram os negócios e os preços das terras nuas até 1927, denunciando um interesse reduzido em investir em novas plantações ${ }^{42}$. No final dos anos 1920 , houve uma recuperação dos valores das terras nuas, aproveitando anos excepcionais de produção e preços do café; contudo, a crise de 1929 eliminaria o novo alento do mercado.

(39) Apesar da larga presença das terras roxas no município, nem todas podem ser classificadas como tal. Provavelmente, as terras sem cafezais, apresentavam condições/qualidades inferiores ou até mesmo impróprias para essa cultura, depreciando seus valores. As indicações, nas escrituras, de tais características apresentam uma frequência muito limitada, dificultando a separação de tais casos. Se ao longo do tempo não houve alteração da qualidade das terras negociadas entre os três grupos, podemos aceitar a comparação, o que nos parece razoável face à inércia da produção agrícola e os custos de mudança para outras terras, especialmente as com cafeeiros.

(40) Das 1.126 transações com informações sobre área, 88,3\% referem-se a negociações de terras com menos de 100 alqueires. Por outro lado, tais negociações envolveram apenas 40,3\% do montante total transacionado. Assim, novamente, demonstramos a existência de uma concentração dos negócios, porém inferior à existente no conjunto das propriedades. Se compararmos as informações sobre o fluxo de negócios com as do censo de 1904-05, verificamos uma maior concentração neste último, pois 70,5\% detinham até 100 alqueires e apenas $7,7 \%$ da área total recenseada.

(41) Excluímos uma de aquisição da Companhia Mogiana de Estradas de Ferro de 12 alqueires por 80 contos de réis, ou seja, por um preço médio muito superior aos demais no referido ano. A proximidade com as linhas da ferrovia provavelmente valorizaram expressivamente essas terras.

(42) Não houve transação de área de terra nua em 1915. A correlação entre o preço do alqueire de terras nuas e o valor médio do café exportado pelo Brasil (ver IBGE, 1990) mostrou-se não significativa $(0,07)$. Entretanto, se analisarmos apenas o período de 1875 a 1914, notaremos uma correlação estatisticamente positiva $(0,45)$, como esperado. Assim, a retração dos preços das terras em Ribeirão Preto decorreu mais de fatores internos ao município do que do mercado nacional ou externo de café. 


\section{Mil-réis de 1913}

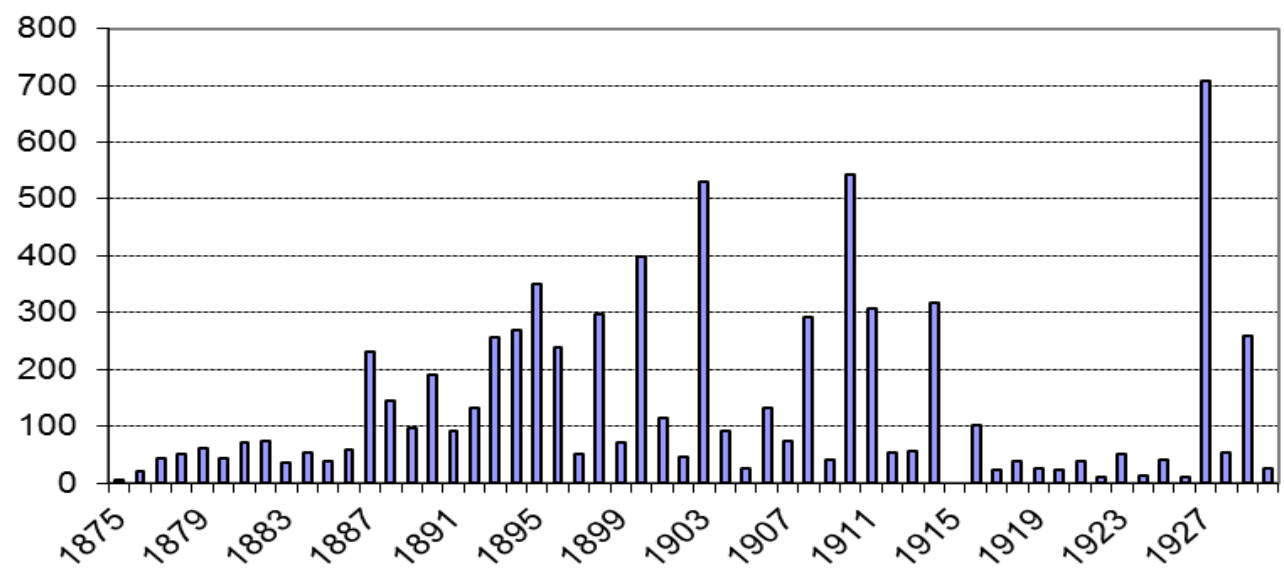

Como esperado para as demais terras, os valores do alqueire revelaram-se, em geral, superiores, conforme o Gráfico 5. A presença de benfeitorias e, principalmente, de cafezais valorizaram os imóveis, incorporando investimentos expressivos ${ }^{43}$.

Gráfico 5

Preço do alqueire segundo ocupação (1874-1930)

Mil-réis de 1913

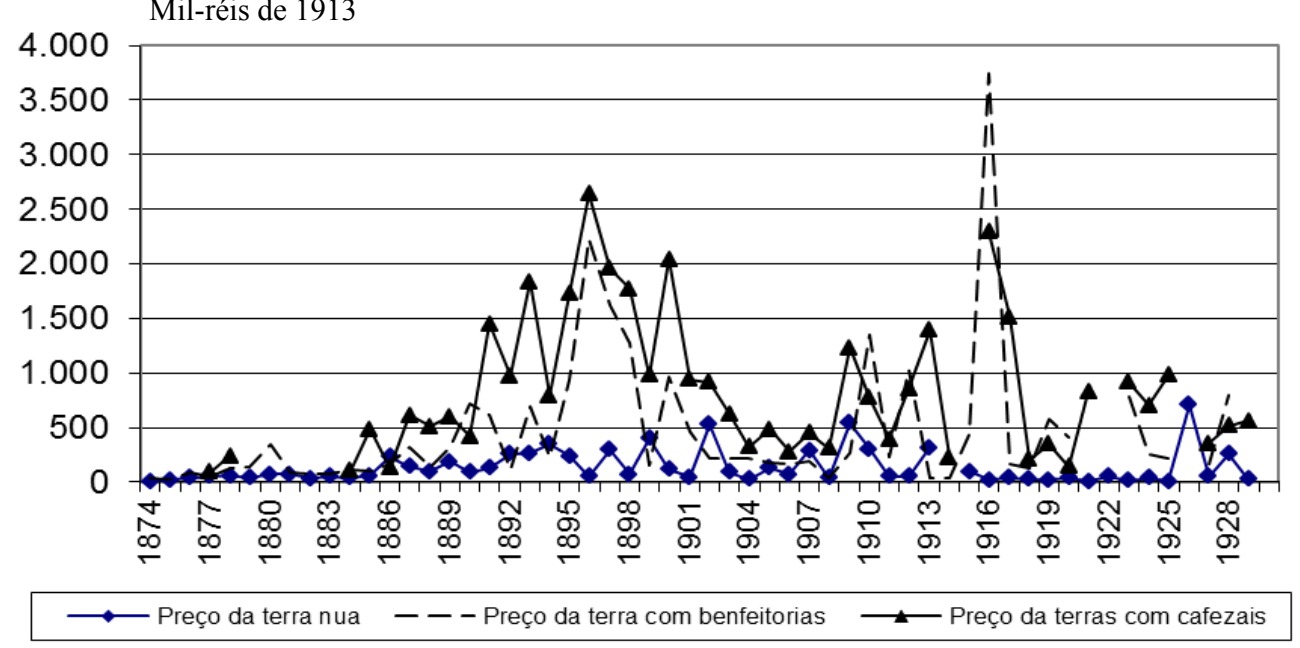

$\mathrm{Na}$ década de 1870, as benfeitorias e cafezais apresentaram valor reduzido, contendo poucas centenas de pés de café. Todavia, os investimentos em novas

(43) É interessante notar que há uma correlação estatisticamente positiva entre o preço do alqueire de terras com benfeitorias e com cafezais $(0,70)$, porém, não há correlação significativa entre esses dois preços e o da terra nua $(0,19$ e $-0,02)$. 
plantações e instalações produziram uma acentuada valorização das propriedades, especialmente até meados da década de 1890. A passagem do século XIX para o século XX deprimiu não apenas os valores totais negociados, mas também os valores do alqueire de todos os tipos de terras, principalmente aquelas com benfeitorias e cafezais. Nos anos anteriores à Primeira Guerra, iniciou-se uma recuperação que, no entanto, foi interrompida pela própria guerra. A partir desse momento, as terras com benfeitorias e cafezais mantiveram, relativamente, seu valor em comparação com as terras nuas, que dependiam da demanda de novos investimentos, à exceção dos anos posteriores à geada. Apenas nos últimos anos em estudo, houve novamente uma aproximação entre os valores das terras nuas e as demais.

\section{Considerações finais}

O mercado imobiliário nos forneceu uma visão das transformações decorrentes da chegada, expansão e declínio da cafeicultura. O café foi introduzido na década de 1870 no município de Ribeirão Preto, e os grandes investimentos no plantio ocorreram a partir da década seguinte até o final do século. Os negócios imobiliários apresentaram um boom extraordinário nesse momento, expandindo enormemente o número e os valores das transações, especialmente nos três últimos lustros do século XIX. Os preços das terras disponíveis para novos cultivos cresceram muito rapidamente nessa época.

Como esperado para essa cultura, a produção demorou alguns anos para atingir o seu apogeu, apenas no início do século XX. Uma vez alcançado esse patamar, os negócios tenderam a se reduzir, e os investimentos em novos plantios também acompanharam tal retração. Desse modo, os negócios imobiliários rurais anteciparam os movimentos posteriores da produção do café, aproveitando preços favoráveis de terras na expectativa de ganhos posteriores. O boom de transações relacionou-se mais aos investimentos em cafezais do que a mudanças gerais da legislação fundiária. Na década de 1920, houve uma retração dos preços das terras nuas, salientando o interesse reduzido em transformá-las em cafezais num período de redução da produção de café no município.

Os processos de valorização, estabilização e declínio das transações demarcaram-se nos valores negociados e, principalmente, no preço do alqueire. Apesar da conjuntura nacional e do mercado cafeeiro condicionarem o ciclo dos negócios, os fatores internos ao município também estabeleceram a própria dinâmica do café e dos negócios imobiliários. O comportamento do meio rural mostrou-se distinto do urbano, que atingiu um crescimento mais constante e menos instável decorrente de outras ocupações não tão diretamente relacionadas à cafeicultura. Ao final do período em estudo, o número de transações urbanas superou o de transações rurais com equivalência em termos de valores nos dois 
meios. Assim, antes de 1930, a urbanização vislumbrada por meio dos negócios imobiliários já se mostrava notória.

\section{Referências bibliográficas}

BACELLAR, Carlos de Almeida Prado. Uma rede fundiária em transição. In: BACELLAR, Carlos de Almeida Prado; BRIOSCHI, Lucila Reis (Org.). Na estrada do Anhanguera: uma visão regional da história paulista. São Paulo: Humanitas, 1999.

BRIOSCHI, Lucila Reis et al. Entrantes no sertão do Rio Pardo: o povoamento da freguesia de Batatais: século XVIII e XIX. São Paulo: CERU, 1991.

CABRAL, José Antônio Teixeira. A estatística da Imperial província de São Paulo: com várias anotações do Tenente-coronel José Antônio Teixeira Cabral, membro da mesma estatística. Tomo I, 1827. São Paulo: Edusp, 2009.

CARRARA, Angelo Alves. Ocupação territorial e estrutura fundiária: as Minas e os currais (1674-1850). Estudos de História, v. 8, n. 2, p. 81-97, 2001.

CATÃO, Luis A. V. A new wholesale price index for Brazil during the period 1870-1913. Revista Brasileira de Economia, v. 46, n. 4, p. 519-533, out./dez. 1992.

DENIS, Pierre. O Brasil no século XX. Lisboa: José Bastos \& Cia, s. d.

FALEIROS, Rogério Naques. Fronteiras do café: fazendeiros e "colonos" no interior paulista (1917-1937). Tese (Doutorado em Economia Aplicada)-Instituto de Economia, Universidade Estadual de Campinas, (IE/Unicamp), 2007.

FRANCO, Gustavo. Reforma monetária e instabilidade durante a transição republicana. Dissertação (Mestrado em Economia)-PUC/RJ, Rio de Janeiro, BNDES, 1983.

GODOY, Joaquim Floriano de. A província de São Paulo: trabalho estatístico, histórico e noticioso. 2. ed. São Paulo: Governo do Estado, 1978.

GUIMARÃES, Alberto Passos. Quatro séculos de latifúndio. 4. ed. Rio de Janeiro: Paz \& Terra, 1977.

HOLLOWAY, Thomas H. Imigrantes para o café: café e sociedade em São Paulo, 18861934. Rio de Janeiro: Paz \& Terra, 1984.

IBGE. Estatísticas históricas do Brasil: séries econômicas, demográficas e sociais de 1550 a 1988. 2. ed. rev. Rio de Janeiro: IBGE, 1990.

LIMA, Ruy Cirne. Pequena história territorial do Brasil: sesmarias e terras devolutas. 4. ed. Brasília: ESAF, 1988.

LOPES, Luciana Suarez. A formação do município de Ribeirão Preto e o surgimento do comércio e da indústria. In: ASSOCIAÇÃO Comercial e Industrial de Ribeirão Preto. (Org.). Um espelho de 100 anos: Associação Comercial e Industrial de Ribeirão Preto 1904-2004. 1. ed. Ribeirão Preto: ACI, 2004. p. 167-177. 
MACHADO, Alcântara. Vida e morte do bandeirante. Belo Horizonte/São Paulo: Ed. Itatiaia/Edusp, 1980.

MARCONDES, Renato Leite. O Café em Ribeirão Preto (1890-1940). História Econômica \& História de Empresas, v. 10, p. 171-192, 2007.

MARCONDES, Renato Leite; GARAVAZO, Juliana. Metamorfoses da economia urbana: os estabelecimentos de um município brasileiro (Ribeirão Preto, 1890-1962). Estudos do Século XX, Coimbra, v. 4, p. 255-272, 2004.

MARTINS, José de Souza. O cativeiro da terra. 3. ed. São Paulo: Hucitec, 1986.

MINISTÉRIO DA AGRICULTURA, INDÚSTRIA E COMÉRCIO. Questionários sobre as condições da agricultura dos 173 municípios do Estado de São Paulo: Inspetoria Agrícola do $14^{\circ}$ Distrito de abril de 1910 a janeiro de 1912. Rio de Janeiro: Typ. do Serviço de Estatística, 1918.

MONBEIG, Pierre. Pioneiros e fazendeiros de São Paulo. São Paulo: Hucitec/Polis, 1984.

MORAES, Maria Luiza de Paiva Melo. Companhia Agrícola Francisco Schmidt: origem, formação e desintegração (1890-1924). Dissertação (Mestrado em História) - FFLCH/USP, 1980.

MORAES, Maria Luiza de Paiva Melo. Atuação da firma Theodor Wille \& Cia no mercado cafeeiro do Brasil: 1844-1918. Tese (Doutorado em História)-FFLCH/USP, 1988.

MOTTA, Márcia Maria Menendes. Nas fronteiras do poder. Conflito de terra e direito agrário no Brasil de meados do século XIX. Tese (Doutorado em História)IFCH/UNICAMP, 1996.

MÜLLER, Daniel Pedro. Ensaio d'um quadro estatístico da província de São Paulo. São Paulo: Governo do Estado, 1978.

NOZOE, Nelson Hideiki. Sesmarias e apossamento de terras no Brasil colônia. Revista EconomiA, v. 7, n. 3, p. 587-605, set./dez. 2006.

- A apropriação de terras rurais em São Paulo. Tese (Livre-docência em Economia)-FEA/USP, 2008.

OLIVEIRA, Jorge Henrique Caldeira de; MARCONDES, Renato Leite. Os negociantes de imóveis durante a expansão cafeeira em Ribeirão Preto (1874-1899). Revista Tempo $U F F$, v. 15, p. 111-133, jul. 2003.

OLIVEIRA, Maria Coleta F. A. de. Mercantilização e urbanização de São Paulo. In: ENCONTRO NACIONAL DE ESTUDOS POPULACIONAIS, 6, Belo Horizonte, 1988. Anais.... Belo Horizonte: ABEP, v. 2, p. 307-342, 1988.

PRADO JÚNIOR, Caio. Divisão da propriedade fundiária rural no Estado de São Paulo. Boletim Geográfico, Ano III, n. 29, ago. 1945. 
PREFEITURA MUNICIPAL DE RIBEIRÃO PRETO. Relatório de 1902 apresentado a Câmara Municipal de Ribeirão Preto pelo prefeito Dr. Manoel Aureliano de Gusmão. São Paulo: Duprat, 1903.

SAMPAIO, Antonio Carlos Jucá de. Na curva do tempo, na encruzilhada do Império: hierarquização social e estratégias de classe na produção da exclusão (Rio de Janeiro, c.1650-c.1750). Tese (Doutorado em História)-PPH/UFF, 2000.

. O agro fluminense na curva do tempo: 1650-1750. Estudos de História, v. 8, n. 2, p. 99-130, 2001.

SECRETARIA DA AGRICULTURA, COMÉRCIO E OBRAS PÚBLICAS. Estatística agrícola e zootécnica de Ribeirão Preto no ano agrícola de 1904-1905. São Paulo: Typ. Brazil/Rothschild \& Co., 1907.

SILVA, Lígia Osório. Terras devolutas e latifúndio: efeitos da lei de 1850. Campinas: Ed. da Unicamp, 1996.

VUGMAN, Gitel. Companhia Mogiana de estradas de ferro e navegação (1872-1974): subsídios para estudo de uma estrada de ferro paulista. Dissertação (Mestrado em História) FFLCH/USP, 1976.

ZAMBONI, Ernesta. Processo de formação e organização da rede fundiária da área de Ribeirão Preto (1874-1900). Estudos de História, v. 8, n. 2, p. 187-208, 2001.

ZAMBONI, Silvio. Café no norte paulista: a crise de 1929 na fazenda Dumont. Dissertação (Mestrado)-ESALQ/USP, 1979. 